\title{
Legal Protection of Consumer Freedom of Opinion in Indonesia
}

\author{
Afrizal Mukti Wibowo ${ }^{1, *}$ \\ ${ }^{1}$ Faculty of Law, Brawijaya University, Malang, Indonesia \\ *Corresponding author. Email: afrizalwibowo@ub.ac.id
}

\begin{abstract}
This article aims to analyze and describe forms of legal protection for consumers who provide opinions on the goods and/or services they use. The position of business actors who are stronger than consumers, sometimes makes consumers afraid to express their opinions about the goods and/or services they use. This research is normative legal research with a case approach regarding the freedom of opinion conveyed by consumers and the actions of business actors towards their consumers. The results of this study are the legal protection of consumer freedom of opinion is respected and guaranteed in Indonesia's Constitution of 1945, Indonesia's Freedom of Expressing Opinions in Public Number 9 of 1998, Indonesia's Consumer Protection Law Number 8 of 1999, Indonesia's Human Rights Law Number 39 of 1999. On the other hand, business actors who feel polluted / harmed by consumer opinions use the Information and Electronic Transaction Law to report it.
\end{abstract}

Keywords: consumer, freedom of opinion, legal protection

\section{INTRODUCTION}

The development of technology and information affects the level of promotion from business actors towards the goods and services they sell to consumers, especially through social media [1]. Unfortunately, this is not accompanied by the knowledge of the people who consume goods or services from business actors [2]. As a result, many consumer complaints are felt against the goods or services they consume.

In some conditions, consumers are reluctant to complain about the goods or services they consume. This is because sociologically consumers have a weaker position than business actors [3]. In fact, along with the development of technology and information as used by business actors, consumers have a platform that can be used to express their opinions through social media or reviews in the marketplace.

In Indonesia, several cases have attracted public attention regarding complaints, or even just honest reviews of goods or services consumed, which are not well received by business actors. In January 2021, the business actor sent an objection letter to the consumer for uploading a video review of the goods he bought from the business actor [4]. The objection letter is to correct or delete the video review content uploaded by consumers.
Another action taken by business actors against consumers freedom of expression through reviews of goods or services is to report to the police. Like what happened in 2019 between an airline and one of its passengers who did the review [5]. In the end, though, the two sides made peace.

The same thing happened in 2020, business actors reported consumers because they said the goods from these actors were not branded [6]. In addition to excessive or repressive actions, of course, many business actors respond both to complaints and reviews from consumers as freedom of opinion and input from consumers. In addition, it also illustrates that the position of consumers is still weak in terms of the freedom to express opinions regarding the goods or services they consume.

Freedom to express opinions both orally and in writing is one of the recognized human rights in a democratic state of law [7]. Freedom of opinion is one of the fundamental characteristics for individuals or humans in the context of self-development that cannot be separated from individual dignity or human values [8]. On the other hand, especially regarding the freedom of opinion, consumers still receive an inappropriate response from business actors and even tend to be repressive. 
Based on the description of the problem, it is important to analyze and describe the legal protection of consumers freedom of opinion in the laws and regulations in Indonesia.

\section{METHOD}

This type of normative legal research [9] means collecting materials from various laws and regulations and using some written literature. Document study research focuses more on analysis and some literature on materials from these data, which are secondary, namely the absolute nature that must be fulfilled and what is written in the document study. Normative juridical law research is a problem that is raised, discussed, and described in this research focused on establishing the rules or norms in positive law. Normative juridical research is carried out by examining various kinds of formal legal authorities such as laws and literature, which are theoretical concepts linked to the problems that are the subject of discussion.

The approach utilized to complete this research is library research, a method used to acquire books on laws and regulations and other materials relating to the subject of study by reading or compiling them. Secondary data was obtained through literature study by analyzing Indonesia's Constitution of 1945, Indonesia's Freedom of Expressing Opinions in Public Number 9 of 1998, Indonesia's Consumer Protection Law Number 8 of 1999, Indonesia's Human Rights Law Number 39 of 1999, and Indonesia's Information and Electronic Law Number 11 of 2008.

\section{RESULTS AND DISCUSSION}

\subsection{Legal Protection of Consumer Freedom of Opinion in Indonesia's Constitution of 1945}

Freedom of opinion has its place in the democratic process in Indonesia. This is in line with what was conveyed by Robert Dahl, that a democratic country must uphold eight democratic values, one of which is the existence of freedom of opinion [10]. The state will be considered democratic when it provides and guarantees the protection of the freedom of opinion of its citizens through any media [11]. The protection and guarantee of freedom of opinion in the legislation are very urgent, considering that freedom of opinion is one of the elements of human rights that underlies political rights.

Article 28 of Indonesia's Constitution of 1945 guarantees The right to association and assembly, as well as the right to express opinions vocally and in writing, are all protected by law. Additionally, Article 28 E paragraph (3) of the 1945 Indonesian Constitution governs and secures everyone's right to organization, assembly, and expression.

Indonesia's Constitution of 1945 provides guarantees of legal protection for citizens' freedom of expression. In line with this, the freedom of expression of consumers must also be respected, protected, and fulfilled by the state, especially by business actors as a human right of consumers.

\subsection{Legal Protection of Consumer Freedom of Expression in Indonesia's Law}

\subsubsection{Indonesia's Freedom of Expressing Opinions in Public Number 9 of 1998}

Internationally, the Universal Declaration of Human Rights (UDHR) regulates the fulfillment of human rights, and freedom of speech is enshrined in article 19, which states that everyone has the right to freedom of opinion and expression, which includes the freedom to hold an opinion without interference and the freedom to seek, receive, and impart information and opinions via any means and without regard for frontiers.

In 1998, along with the reformation, Indonesia's Freedom of Expression of Opinion in Public Law Number 9 of 1998 was born. In Indonesia's Freedom of Expression of Opinion in Public Law Number 9 of 1998 what is meant by Freedom to express opinions is the right of every citizen to express thoughts orally, in writing, and so on freely and responsibly by the provisions of the applicable laws and regulations. Then, in public is in front of many people, or other people, including in a place that can be visited and or seen by everyone. The normative guarantee for freedom of expression is further contained in Article 2 point 1. Specifically, each citizen, individually or in groups, expresses views on how democratic rights and obligations are manifested in the life of society, nation, and state.

However, the freedom to express opinions in public is not unlimited; as specified in Article 4 of Indonesia's Freedom of Expression of Opinion in Public Law Number 9 of 1998, five principles must be considered when expressing opinions in public. These principles include the principle of rights and obligations balance, the principle of deliberation for consensus, the principle of legal certainty and justice, the principle of proportionality, and the principle of consensual expression.

Based on this description, the freedom of consumers to convey is guaranteed by law, but there are limitations contained in several derivative provisions such as Indonesia's Criminal Code and Indonesia's Information and Electronic Transaction Law Number 11 of 2008. 
However, the implementation of Indonesia's Information and Electronic Transaction Law Number 11 of 2008 has caused a lot of controversy and criticism. Indonesia's Information and Electronic Transaction Law Number 11 of 2008 is seen as a barrier to the expression of citizens within the framework of democracy. One of the articles that are considered controversial because it limits people's freedom of opinion, especially on social media, is Article 27 paragraph (3). This article is often used to criminalize citizens who express their opinions openly but are deemed to have disturbed the stability and public order [12]

\subsubsection{Indonesia's Consumer Protection Number 8 of 1999}

National economic development in the age of globalization must be able to support the growth of the business world, enabling it to produce a diverse range of goods and/or services with technological content that benefit the community as a whole while also ensuring consumer certainty over goods and/or services obtained through trade.

As a result, consumer protection is controlled in this manner by Indonesia's Consumer Protection Law No. 8 of 1999 [13]. Consumer protection, as defined in Article 1 of Indonesia's Consumer Protection Law No. 8 of 1999, is defined as "any measures that ensure legal certainty in order to safeguard consumers." Whereas under consumer protection law, a consumer is defined as someone who utilizes goods and/or services accessible in the community for the benefit of himself, his family, other people, and other living species, and not for commercial purposes.

Any individual or business entity, whether legal or not, created and domiciled in or performing business activities on the territory of the Republic of Indonesia, either alone or jointly through agreements to arrange business activity in various economic spheres is a business actor. One of the aims of Indonesia's Consumer Protection Law No. 8 of 1999 is to establish a consumer protection system that incorporates features of legal certainty, information disclosure, and information access.

To this end, Article 4 letter $d$ of Indonesia's Consumer Protection Law No. 8 of 1999 controls consumers' right to have their comments and concerns about the goods and/or services they have purchased heard. However, unfortunately, Article 7 of Indonesia's Consumer Protection Law Number 8 of 1999 does not regulate the obligation of business actors to hear opinions and complaints from consumers and how to respond to them. So that it can be found that there are consumer cases reported by business actors because of their opinions about the goods and/or services they use.

\subsubsection{Indonesia's Human Rights Number 39 of 1999}

Freedom of opinion and freedom to seek, receive and impart information and ideas through any media, is one of the human rights standards widely recognized in international forums [14]. These international instruments were later adopted in national law in Indonesia, one of which was Indonesia's Human Rights Number 39 of 1999. Humans, as God Almighty's creatures charged with the responsibility of managing and maintaining the universe with complete devotion and accountability for the welfare of mankind, were endowed with human rights to ensure the continued existence of the dignity and glory of God and the harmony of the environment.

Human rights are fundamental rights that are inherent in humans, universal, and irreversible; as such, they must be preserved, respected, and maintained, and should not be neglected, diminished, or revoked by anybody. Consumers' freedom of opinion is guaranteed by Article 23 paragraph (2) of Indonesia's Human Rights Law No. 39 of 1999, which states that everyone has the right to have, express, and disseminate opinions according to his conscience, orally and in writing via print and electronic media, with due regard for religious values, moral order, public interest, and the nation's integrity. Additionally, Article 25 of Indonesia's Human Rights Law No. 39 of 1999 provides that everyone has the right to express their thoughts in public, including the right to strike in accordance with the law's regulations.

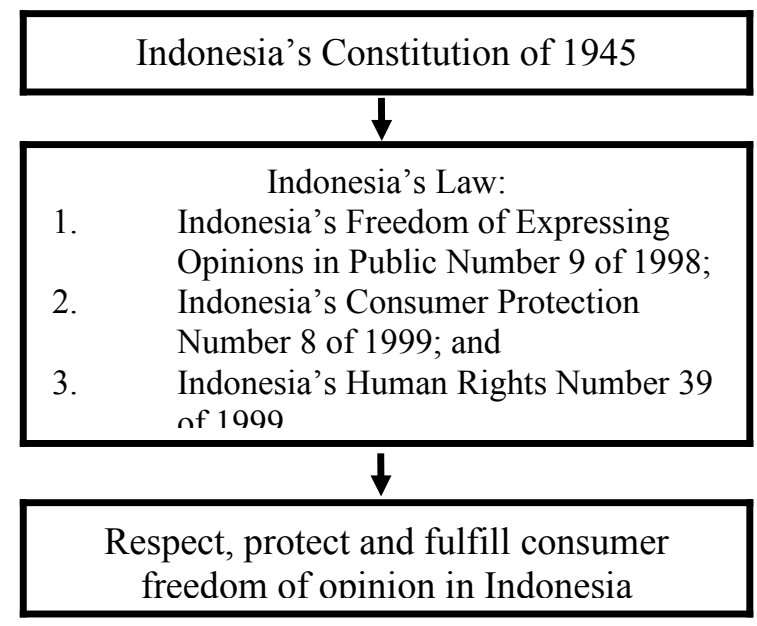

Figure 1 Legal Protection of Consumer Freedom of Opinion in Indonesia

Every citizen has the right to express his thoughts orally, in writing, and so on freely and with responsibility by the provisions of the applicable laws and regulations. This means that the State of Indonesia recognizes and guarantees the rights to freedom of association, assembly, and opinion. This includes 
freedom of opinion conveyed by consumers for the goods and/or services that they use.

However, freedom of speech is not absolute. Both in international instruments such as the ICCPR, as well as in national laws and regulations such as Indonesia's Constitution of 1945 and Indonesia's Human Rights Number 39 of 1999, It is stated that in exercising their rights and liberties, everyone is required to adhere to the restrictions imposed by law in order to ensure the recognition and respect for the rights and liberties of others and to meet reasonable demands based on moral, security, and public order considerations in a democratic society.

Limitations on freedom of opinion are also regulated in several other regulations such as the Criminal Code which regulates prohibited acts including insults, defamation, slander, blasphemy of religion, and hate speech. There is also Indonesia's Information and Electronic Transaction Law Number 11 of 2008 which regulates restrictions on actions taken in cyberspace.

\section{CONCLUSION}

Legal protection of consumer freedom of opinion is respected and guaranteed in Indonesia's Constitution of 1945, Indonesia's Freedom of Expressing Opinions in Public Number 9 of 1998, Indonesia's Consumer Protection Law Number 8 of 1999 and Indonesia's Human Rights Law Number 39 of 1999. Seeing the various rules above, consumers can enjoy the freedom of opinion both in the real world and in the virtual world. However, the freedom of opinion guaranteed by the constitution must not violate the rights of others. In its implementation, several cases have received public scrutiny which not only questions the fairness and limits of freedom of opinion regulated in the various laws and regulations but also assesses the extent to which the general public, especially consumers, understand the freedom they have and also the extent to which law enforcement officers interpret freedom. argued in various cases.

The ideal is that there is a common perception of freedom of opinion between the general public and law enforcement officers. However, there are several cases related to freedom of opinion which has become polemic among the Indonesian people, which can be caused by different understandings, especially with the freedom of opinion of consumers who have a weak position compared to business actors. On the other hand, business actors who feel polluted / harmed by consumer opinions use the Information and Electronic Transaction Law to report it. Especially it cause damage. Especially if it causes harm to business actors regardless of whether the consumer's freedom of opinion is right or wrong.

\section{REFERENCES}

[1] Sulianta. 101 Jurus Promosi Online Paling Top. Jakarta: Elex Media Komputindo, 2014.

[2] Wibowo, A. M., Sukarmi, S., \& Hamidah, S. Analisis Yuridis Kewenangan Penyelesaian Sengketa Pembiayaan Konsumen Di Indonesia. Legality : Jurnal Ilmiah Hukum, 2019, 27(1), 4153. Retrieved from https://ejournal.umm.ac.id/index.php/legality/articl e/view/8957

[3] Howells, G., \& Weatherill, S. Consumer Protection Law: Edition 2. London and New York: Routledge Taylor \& Francis Group. 2017.

[4] Tirto.id. (2021). Kronologi Kasus Eiger vs Youtuber duniadia yang Viral di Twitter. (Online). Retrived from https://tirto.id/kronologi-kasuseiger-vs-youtuber-duniadian-yang-viral-di-twitter$\underline{\mathrm{f9KA}}$

[5] Kompas.com. (2019). Kronologi Youtuber Rius Vernandes Dilaporkan Garuda Indonesia hingga Berakhir Damai. (Online). Retrived from https://megapolitan.kompas.com/read/2019/07/19/2 0094841/kronologi-youtuber-rius-vernandesdilaporkan-garuda-indonesia-hingga?page=all

[6] Sumeks.co. Dibilang Jual Barang Palsu, Pengusaha Butik di Mall Laporkan Konsumen ke Polisi. (Online), 2020. Retrived from https://sumeks.co/dibilang-jual-barang-palsupengusaha-butik-di-mall-laporkan-konsumen-kepolisi/

[7] Tilly, C. Democracy. New York: Cambridge University Press, 2007.

[8] Baker, E. Human Liberties and Freedom of Speech. Oxford University Press, 1989.

[9] Wibowo, A. M. Perbandingan Hukum Arbitrase dan Alternatif Penyelesaian Sengketa Arbitrase Online Indonesia dan Cina. Audito Comparative Law Journal (ACLJ), 2(2), 2021. 110-118. Retrieved from https://ejournal.umm.ac.id/index.php/audito/article/ view/16372

[10] Yuniarto, B. Pendidikan Demokrasi dan Budaya Demokrasi Konstitusional. Yogyakarta: Deepublish, 2018

[11] Johson, J. W. Peran Media Bebeas (Office of International Program U.S. Departement of State, 2001. 
[12] Sidik, S. Dampak Undang-Undang Informasi dan Transaksi Elektronik (UU ITE) Terhadap Perubahan Hukum dan Sosial Dalam Masyarakat. Jurnal Ilmiah WIDYA, Vol. 1, Number 1, Mei-Juni 2013, p-1-7.

[13] Wibowo, A. M., Sukarmi \& Hamidah, S. Dasar Pertimbangan (Ratio Decidendi) Hakim Dalam Memutus Sengketa Pembiayaan Konsumen. Fakultas Hukum Universitas Brawijaya, Konferensi Nasional Hukum Bisnis, 2019.

[14] European Convention on Human Right, Article 10, Paragraph 2; Dijk, P.V. et.al. Theory and Pratice of the European Convention on Human Rights $\left(4^{\text {th }}\right.$ Edition), Antwerpen, 2006. 